JOURNAL OF SECURITY AND SUSTAINABILITY ISSUES

ISSN 2029-7017/ISSN 2029-7025 (online)

2020 Volume 10 Number (October)

http://doi.org/10.9770/jssi.2020.10.Oct(3)

Scopus ${ }^{\circ}$

\title{
INDUCING ORGANIZATIONAL CITIZENSHIP BEHAVIOR THROUGH GREEN HUMAN RESOURCE MANAGEMENT BUNDLE: DRAWING IMPLICATIONS FOR ENVIRONMENTALLY SUSTAINABLE PERFORMANCE. A CASE STUDY
}

\author{
Yuris Danilwan ${ }^{1 *}$, Dewi Budhiartini Yuli Isnaini² ${ }^{2}$ Ikbar Pratama $^{3}$, Dirhamsyah ${ }^{4}$ \\ ${ }^{1,4}$ Politeknik Adiguna Maritim Indonesia (POLTEK AMI) Medan, Indonesia \\ ${ }^{2}$ Faculty of Economics Management, Universitas Amir Hamzah, Medan, Indonesia \\ ${ }^{3}$ Fakultas Ekonomi dan Bisnis, Universitas Medan Area, Medan, Sumatera Utara, Indonesia \\ Corresponding Authors: ${ }^{1^{*}}$ yurisdanilwan1959@gmail.com, ${ }^{3 *}$ ikbar.p@gmail.com
}

Received 10 November 2019; accepted 18 June 2020; published 30 October 2020

\begin{abstract}
Organizations have faced pressure from their stakeholders to adopt environmentally friendly business practices since the last few decades, which creates a major problem in front of their management to sustain their position in the highly competitive market. In order to retain its strategic image among the stakeholders' minds, there is a need to develop some green practices in its human resources department that boost its sustainability. In this paper, there is a brief description regarding how these green HRM bundles caused a major impact on environmental sustainable performance. Its independent variables are; green hiring, green training \& involvement, and green performance management \& compensation. While organizational citizenship behavior acts as a mediator between independent and dependent variables. An online survey-based quantitative data collection method is used where 402 participants' data is considered to apply the SPSS test i.e. structural equation modelling. The majority of the participants' results show that green performance management \& compensation cause a major influence on organizational citizenship behavior and environmental sustainable performance. While green hiring has, the least impact and green training \& involvement show the moderate outcome on the dependent and mediating variable. This study is an informative approach for the Indonesian healthcare sector and its management to make some efficient changes in its HR policies, and also this data will add value in the decision making process of this state policymakers and other research fellows. Indeed, this is important research, but there are also some limitations like lack of mixed research, and Indonesia state-based restricted research can affect the acceptability of this analysis. This gap can fulfill by upcoming scholars in their research journals.
\end{abstract}

Keywords: Green Hiring; Green Training \& Involvement; Green Performance Management \& Compensation; Organizational Citizenship Behavior; Environmental Sustainable Performance.

Reference to this paper should be made as follows: Danilwan, Y., Isaini, D. B. Y., Pratama, I., Dirhamsya. 2020. Inducing organizational citizenship behavior through green human resource management bundle: drawing implications for environmentally sustainable performance. A case study. Journal of Security and Sustainability Issues, 10(Oct), 39-52. http://doi.org/10.9770/jssi.2020.10.Oct(3)

Jel Codes: M5, M12

\section{Introduction}

The health care sector of Indonesia has been somehow engaged in green human resource administration (GHRA) practices such as green involvement and training, green hiring, and green performance compensation and management (Pasharibu, Sugiarto, Ariarsanti, \& Wijayanto, 2019; Ahmed, et al., 2020, Mazzoni, 2020). Previously, this sector did not use green human resource supervision activities much. Today, green HRM activities are directly contributing to the upgraded environmental sustainability performance of the sector through the use of organizational citizenship behavior (Amrutha \& Geetha, 2020; Nuryakin, Maryati, 2020; Kanwal, et al., 2020). According to Ahmed, AlZgool, and Shah (2019) green HRM mainly includes the contribution of HRM practices and policies towards the wider corporate environmental outline. It includes the use of every worker to nurture sustainable practices in the industry and the enhancement of employee awareness regarding sustainability. Green hiring involves the consideration of environmentally friendly activities to attract the employees to work for 
their green employers (Cheema \& Javed, 2017). Besides, green training and involvement (GTI) also help a company in improving its sustainable development (Zaid, Jaaron, \& Bon, 2018; Reinhold, Järvis, \& Prause, 2019: Bombiak, 2019).

Here, there is a figure 1 that shows the green hired persons in Indonesia during 2014-2020.

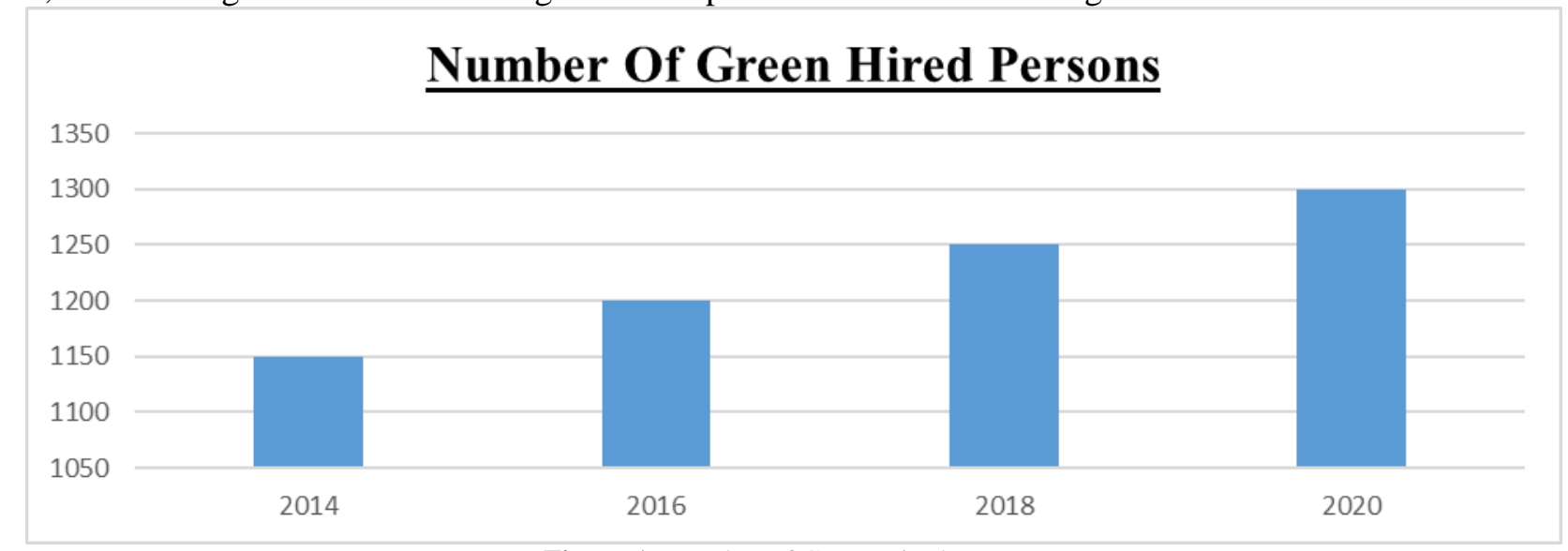

Figure 1: Number of Green Hired Persons

Lastly, green performance compensation and management involve the use of a green indicator or standard to advance the environmental performance of a company (Zaid, Bon, \& Jaaron, 2018). In this way, green HRM practices directly contribute to the improvement in sustainability performance (Bon, Zaid, \& Jaaron, 2018). The following table 1 shows some significant green human resource management practices (along with indicators) used in the healthcare sector of Indonesia.

Table 1. Indicators of green HRM practices

\begin{tabular}{ll}
\hline Green HRM practices & Indicators \\
\hline Performance standards & $\begin{array}{l}\text { Determine relevant standards, select indicators, set objectives } \\
\text { and targets }\end{array}$ \\
\hline Performance measurement & $\begin{array}{l}\text { Refine indicators and define measures, develop data systems } \\
\text { and collect data }\end{array}$ \\
\hline Reporting of progress & $\begin{array}{l}\text { Analyze data feedback to managers and develop a regular } \\
\text { reporting cycle }\end{array}$ \\
\hline Quality process & Use data for decisions to enhance programmers and policies \\
\hline
\end{tabular}

Kim, Kim, Choi, and Phetvaroon (2019) in a study illustrates that green HRM practices are very important for a sector as these practices lead to improved environmental sustainability. However, the health care sector of Indonesia has been facing some issues of environmental sustainability performance because of the reduced use of green human resource administration practices. The firms in this sector do not engage in activities like green employment, green performance compensation and management, and green training and participation (Assyofa, Rani, \& Yuliawati, 2020; Chen \& Gao, 2020). This situation is leading the sector to low sustainability performance, which needs to be mitigated.

Different previous researchers have identified and manifested the importance of green human resource management (GHRM) practices. The recent research by Bon et al. (2018) has made a significant and clear vision as green practices involve some crucial steps that play a significant role to improve the overall performance and value of the firm. The previous efforts lack in describing the entire impact of GHRM practices through green training programs and green wiring on environmentally sustainable performance (ESP). The given research article has a very detailed as well as a significant description of improving ESP of the health care industry of Indonesia. 
JOURNAL OF SECURITY AND SUSTAINABILITY ISSUES

ISSN 2029-7017/ISSN 2029-7025 (online)

2020 Volume 10 Number (October)

http://doi.org/10.9770/jssi.2020.10.Oct(3)

Moreover, in the past, several analysts such as Astuti and Wahyuni (2018) have explained the significance of green practices as well as the interrelationship between green management and sustainable performance. However, this research is crucial and justified because no other effort has described the relationship between GHRM practices and ESP of the health care sector of Indonesia. The current research has the following objectives,

- The first objective of the research is to evaluate the impact of green hiring of GHRM on environmentally sustainable performance in the healthcare sector of Indonesia.

- The second aim of the study is to identify the impact of green training and involvement on sustainable performance in the healthcare sector of Indonesia.

- The next aim of the study is to examine the impact of green performance management and compensation on the environmentally sustainable performance in the healthcare sector of Indonesia.

- The fourth objective of the study is to analyze the mediating role of organizational citizenship behavior (OCB) in the relationship between green hiring and ESP in healthcare sector of Indonesia.

- Another aim of the research is to identify the mediating impact of OCB on the association b/w green training and involvement and ESP in healthcare sector of Indonesia.

- The final purpose of the study is to evaluate the mediating impact of OCB on the linkage b/w green performance management and ESP in the healthcare sector of Indonesia.

This research and its findings prove to be significant for the health care sector of Indonesia, as Indonesia has been a significant and effective structure of health care. Indonesia is a strong as well as influential country thus the findings of this research prove to be very helpful and supportive for the health care sector of Indonesia. The health care industry has huge importance for the nation this is mainly because it is a sector that is very important for the nation's life (Groves, Kayyali, Knott, \& Kuiken, 2016; Chen, Qisheng, et al., 2020). The overall results and suggestions made by this research study have a wider scope as well as significant for the Indonesian health care sector majorly due to the fast-developing sector in terms of health activities.

The research paper mainly consists of five chapters to illustrate the detailed description of the following chapters. These chapters consist of the following topics such as introduction, review of the previous literature, research methodology, data analysis, and discussion, and conclusion. The first chapter expresses the background of the study, problem statement, justification and rationale, research objectives and research questions, and significance and the scope of the study. The literature review chapter discusses the variables, mediators, dependent and independent variables, and the previous studies are analyzed briefly. Research methodology explains the methods and techniques to gather information or data. Finally, the last chapters discuss the interpretation of results and discussion and conclusion.

\section{Literature review}

\subsection{Theory of green human resource management}

During the past few years, green human resource management (GHRM) has emerged as a significant trend of successful human resource management and combines as well as integrates environmental management and sustainable firm performance in a little to enhance and support a particular sector performance (Ren, Tang, \& Jackson, 2018). According to the theory of GHRM, green management is essential for many organizations as it ensures sustainable as well as significant environmental performance majorly through a positive set of policies and practices that stimulate green behavior (Guerci \& Carollo, 2016). The given theory is mostly used in different studies to refer to the contribution of HRM regulations and policies mainly towards the significant corporate environmental purposes that further enhance the environmental sustainable performance (ESP). According to Yong, Yusliza, Ramayah, and Fawehinmi (2019), the following theory also used to refers to incorporating every individual of the sector to support sustainable processes and enhance individual awareness and commitments on 
JOURNAL OF SECURITY AND SUSTAINABILITY ISSUES

ISSN 2029-7017/ISSN 2029-7025 (online)

2020 Volume 10 Number (October)

http://doi.org/10.9770/jssi.2020.10.Oct(3)

the challenge of environmental sustainability. According to Anjana Nath green, HR are positive eco-friendly HR practices leading to better efficiencies, effective as well as sustainable performance in terms of environment ( $\mathrm{Yu}$, Chavez, Feng, Wong, \& Fynes, 2020). Furthermore, the theory of GHRM also described that green human management practices help many sectors to minimize the insignificant impacts of their daily operations on the environment which in turn improves and sustains the environmental performance (Singh, Del Giudice, Chierici, \& Graziano, 2020).

\subsection{Relationship b/w green hiring (GH) and environmental sustainable performance (ESP)}

Currently, different sectors and organizations are becoming more and more conscious of the significance of practicing sustainable practices and development in the workforce, for example, according to (Mousa \& Othman, 2020; Pratama et al., 2020) entirely for the reputation it develops as an environmentally responsible sector, as well as for the operational advantages that permeate throughout the development. As a health care sector becomes more conscious of the advantages of an eco-friendly workplace and conditions, it is significant to also incorporate a green hiring strategy with a strong focus on improving as well as stimulating ESP (Pratama et al., 2019; Zaid et al., 2018). A study by Lubis et al., (2019); Wongleedee (2020) manifests that in today's age of sustainability, the new workforce of employees is majorly pushing for employers to focus green practices and develop a sustainable workforce that further helps organizations to increase their ESP. Presently, many sectors in Asian countries aim to develop job descriptions and seats that can manifest a significant number of environmental challenges and problems that are majorly connected to roles and duties of the job being published (Roscoe, Subramanian, Jabbour, \& Chong, 2019). This is mainly because applying green and eco-friendly practices can captures employees to the job for a green mission which enables many sectors to enhance the overall ESP. So, from the above discourse the study proposes the following hypotheses;

H1: Green hiring positively relates to environmental sustainability performance.

\subsection{Relationship b/w green training and involvement and ESP}

Green training and involvement (GTI) are described as an essential priority for any organization as it enables the organization to sustain its development (Amrutha \& Geetha, 2020). It is also very necessary for effecting successful activities regarding environmental management and also cleaner production. According to Birou, Green, and Inman (2019) there is a piece of clear evidence that any organization that involves GTI has a better improvement in skills, knowledge, and awareness about material and processes. These two factors are the whole process as green training helps in finding the means and sources of utilizing the available resources in the best possible way and the result of this green training creates harmony and a peaceful atmosphere for sustainability performance (Hussain, Kamarudin, Thaker \& Salem, 2019). The organizations are trying to find means and sources to cut down their expenses, create new markets, and the production with a minimum low cost. The new and positive reforms, skills, and innovations play a very significant in the sustainable performance of the organization.

H2: Green training and involvement positively relate to ESP.

\subsection{Relationship b/w green performance management (GPM) and compensation and ESP}

The process of green performance management (GPM) and compensation involves the adoption of a green indicator and standard that helps in cultivating the environmental sustainability performance of businesses (Ojo \& Raman, 2019). GPM mainly involves the identification of green aims for all the workers, which assists in translating the environmental objectives into action plans (Owino \& Kwasira, 2016). Different monitoring and reward systems are included in green performance compensation and management, which help in motivating the employees to work for ecological sustainability (Mishra, 2017). Thus, when the employees work better, the environmental sustainability performance of the sector is enhanced. This shows that there is a constructive connection between environmental sustainability presentation and green performance management (Adriana, Fahira, Nailissa'adah, \& El Maula, 2020). This is because GPM provides many green compensation benefits to different sustainable projects of a company, leading to an improvement in ES performance. This relationship is 
JOURNAL OF SECURITY AND SUSTAINABILITY ISSUES

ISSN 2029-7017/ISSN 2029-7025 (online)

2020 Volume 10 Number (October)

http://doi.org/10.9770/jssi.2020.10.Oct(3)

also supported by the theory of green human resource management (GHRM). According to GHRM, GPA is very important for a company because it ensures significant and sustainable environmental performance through the use of positive practices and policies.

H3: There is a positive association between GPM and compensation and ESP.

\subsection{The mediating role of organizational citizenship behavior $(\mathrm{OCB})$ in the relationship $\mathrm{b} / \mathrm{w}$ GH and ESP}

According to research by Jiang, Zhao, and Ni (2017) OCB is an employee's voluntary as well as elective commitment within a sector or firm that is not part of his responsibilities and duties at work. Research studies like (Afsar \& Badir, 2016) demonstrate that OCB majorly deals with behaviors and actions that are not needed by employees. They are important to the job, but benefit the sector as well as a team and encourage even ESP and sector efficiency in terms of environmental performance. The mediating role of OCB can play a major role in improving the performance of the sector regarding the environment majorly by contributing optimally to the sector and avoid burnout. During the last few years, different researches and meta-analysis have carried out to look at the association between OCBs and health care sector performance and achievements in terms of the environment (Hussain et. al., 2020). A study by Trong Tuan Luu (2019) found that OCBs were significantly related to unit-level as well as entire level performance and overall environmental performance. Thus, from the entire above discussion, the study recommends the following hypotheses,

H4: OCB significantly mediates the relationship b/w green hiring and ESP.

\subsection{The mediating impact of $O C B$ on the association b/w GTI and ESP}

According to Yow (2016) in administrative and industrial mindset, organizational citizenship behavior (OCB) refers to the intended pledge of a person with a company or organization that is not involved in his contractual tasks. Green human capital can be deliberated as a major element for organizational citizenship behavior (Pham, Tučková, \& Jabbour, 2019). It has been observed that organizational citizenship behavior helps a company in implementing an environmental approach, which leads to the increase in the knowledge, awareness, and skills of the employees regarding green human resource administration practices. Thus, in this way, organizational citizenship behavior directly contributes to the incorporation of green training and involvement (GTI) in a company. According to the theory of green human resource management, GTI leads to the high environmental sustainability performance of the company by encouraging the employees of the organization to work hard and fulfill its environmental objectives (Lu, Yue, Han, \& Chen, 2018). In this way, the ESP of the company is improved to a great extent. Thus, it has been observed that OCB enhances the relationship between green involvement and training and environmental sustainability performance.

H5: OCB has a positive mediating impact on the association b/w GTI and ESP.

\subsection{The mediating role of $O C B$ in the relationship b/w GPM and ESP}

Organizational citizenship behavior helps the employees of a company to feel more control over their job and activities and feel noble about helping others (Tuan Trong Luu, 2017). It can be assessed by evaluating how often workers show discretionary and extra-role behaviors. According to Zhao and Zhou (2019), the adoption of organizational citizenship behavior helps a company in improving its green performance management. This is because organizational citizenship behavior encourages a company to adopt a green indicator and standard in their operations. In this way, it assists in identifying the environmental objectives of the company and incorporating them into daily activities (Jiang et al., 2017; Valencia et al., 2020). Thus, organizational citizenship behavior directly contributes to the improvement in green performance management and compensation in the company. According to Niyomdecha and Yahya (2019), GPM leads to improved environmental stability by providing green compensation benefits. This fact is also supported by the theory of green human resource management, conferring to which GPM can assist many sectors in reducing the insignificant influence of their daily activities on their environmental sustainability. Thus, OCB plays a positive role in enhancing the association between GPM and compensation and ES performance.

H6: OCB plays a positive mediating role in the connection b/w GPM and ESP. 
Research model is presented in Figure 2 below.

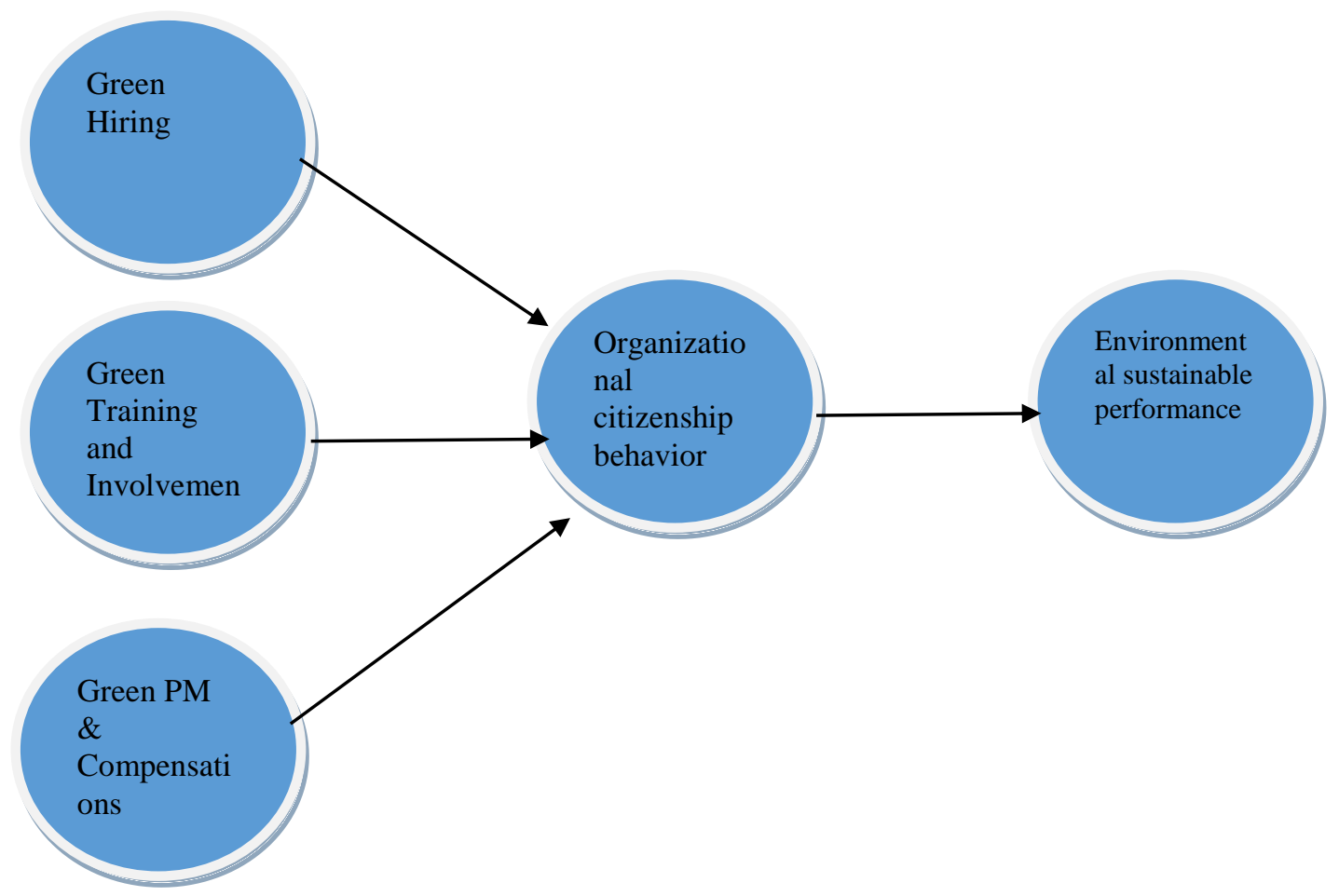

Figure 2: Research Model

\section{Methodology}

A primary research-based quantitative data collection method is conducted in order to collect the relevant outcome and justify or nullify the hypothesis (Dreyer, Macedo, \& Velentgas, 2019; Hameed, Basheer, Iqbal, Anwar, \& Ahmad, 2018). In this data collection procedure, the healthcare sector based working employees, students, and management are majorly considered to collect the online survey outcomes. An online questionnaire was distributed among people through a non-probability convince based sampling method to collect the relevant respondent experience regarding the green human resource management bundle. The five-point Likert scale is used that range from $1=$ strongly disagree, $2=$ disagree, $3=$ neutral, $4=$ agree and $5=$ strongly agree. In this paper, the Green Human Resource Management Practices like Green Hiring, Green Training \& Involvement, and Green Performance Management \& Competition, are considered as independent variables that impact on Environmental Sustainable Performance, as a dependent variable. While, the Organizational Citizenship Behavior is studied as a mediating variable that plays a major role in strengthening the relationship between the independent and dependent variables. According to the statistics, All-around 500 online questionnaires were distributed to the relevant respondent and 402 of them show their valid responses to justify the hypothesis of this study. 
According to the gender-based segregations, 222 participants are males (55.2\%), while remaining 180 participants are females $(44.8 \%)$, this shows that the frequency of male gender is much higher as compared to the female gender. While, in the age based demographic outcomes, 126 are less than 25 years old with $31.3 \%, 166$ are within the age group of 25 to 35 years old (41.3\%), 95 are between the age limit of 35 to 45 years old (23.6\%) while remaining 15 (with 3.7\%) are more than 45 years old. The respondents' outcome shows that majority of the respondents are within the age limit of 21 to 35 and all of them are freshly jobholders and students of this industry. In case of their experience perspectives, $15 \%$ of the respondents having less than two years' experience, $42 \%$ having two to five years medical job experience, $33 \%$ are five to eight years old, and only $10 \%$ having more than eight years' experience in the related field. That means majority of the respondents are young people and having new ideas regarding green marketing.

In order to collect the relevant outcomes, the KMO and Bartlett's test is used to identify the model fitness, and after this, the structural equation modelling based SPSS statistical test is used to derive a constructive outcome (Center, 2018; Prasad, Rao, \& Vaidya, 2019). In addition to this, convergent and discriminant validity, and confirmatory factor analysis are used in order to depict the effective variables uploading and evaluate their threshold range (McGuire, Drost, \& Zhang, 2016; Rimkeviciene, Hawgood, O'Gorman, \& De Leo, 2017; Tarhini, Teo, \& Tarhini, 2016). In the structure model, the clear relationship between the exogenous and endogenous construct is defined.

\section{Analysis Interpretation}

In order to critically evaluate the impact of green human resource management practices on the environmental sustainable performance factor, the following descriptive statistics explored all the related outcomes.

Table 2: Descriptive Statistics

\begin{tabular}{llllllll}
\hline & $\mathrm{N}$ & Minimum & Maximum & Mean & Std. Deviation & Skewness \\
\cline { 2 - 7 } & Statistic & Statistic & Statistic & Statistic & Statistic & Statistic & Std. Error \\
\hline GreenHire & 402 & 1.00 & 5.00 & 3.2939 & 1.01875 & -.258 & .122 \\
GreenTrIn & 402 & 1.00 & 5.00 & 3.4289 & .99193 & -.442 & .122 \\
GreenPM & 402 & 1.00 & 5.00 & 3.5480 & 1.16480 & -.581 & .122 \\
OrgCitBeh & 402 & 1.00 & 5.28 & 3.4572 & 1.10224 & -.546 & .122 \\
EnvSPerf & 402 & 1.00 & 5.00 & 3.5962 & 1.11844 & -.593 & .122 \\
Valid N (listwise) & 402 & & & & & & \\
\hline
\end{tabular}

According to the above mentioned descriptive statistic table 2, it becomes concluded that the standard deviation of green training \& innovation value is less deviated from its mean position as compared to the other variables, while green performance management $\&$ compensation variable highly deviates from its standard mean position. It means that the influence of less deviated variable is much higher on the environmental sustainable performance. While, the standard error of these statistics is 0.122 with the mean value within the range of 3.2 to 3.5 . Its related KMO and Bartlett's test based tabular description is given below (Table 3).

Table 3: KMO and Bartlett's Test

\begin{tabular}{lll}
\hline \multicolumn{2}{l}{ Kaiser-Meyer-Olkin Measure of Sampling Adequacy. } & .951 \\
& & \\
Bartlett's Test of Sphericity & Approx. Chi-Square & 18199.888 \\
& df & 561 \\
& Sig. & .000 \\
\hline
\end{tabular}


According to the above-mentioned test statistics, it becomes concluded that the Kaiser-Meyer-Olkin measure of sampling adequacy value is 0.932 means within their threshold range. In addition, its variable difference value is 300 along with 0.000 significance value (lower than 0.05 ) which depicts that this model is a good fit to make a constructive analysis based outcome. Its rotated component matrix-based variables' outcomes are shown in the following table 4 .

Table 4: Rotated Component Matrixa

\begin{tabular}{|c|c|c|c|c|c|}
\hline & \multicolumn{5}{|c|}{ Component } \\
\hline & 1 & 2 & 3 & 4 & 5 \\
\hline GH1 & & & & .821 & \\
\hline $\mathrm{GH} 2$ & & & & .849 & \\
\hline GH3 & & & & .803 & \\
\hline GH4 & & & & .787 & \\
\hline GH5 & & & & .814 & \\
\hline GH6 & & & & .833 & \\
\hline GT1 & & .773 & & & \\
\hline GT2 & & .680 & & & \\
\hline GT3 & & .739 & & & \\
\hline GT4 & & .821 & & & \\
\hline GT5 & & .793 & & & \\
\hline GT6 & & .839 & & & \\
\hline GT7 & & .865 & & & \\
\hline GT8 & & .861 & & & \\
\hline GP1 & .846 & & & & \\
\hline GP2 & .816 & & & & \\
\hline GP3 & .792 & & & & \\
\hline GP4 & .847 & & & & \\
\hline GP5 & .871 & & & & \\
\hline GP6 & .859 & & & & \\
\hline GP7 & .874 & & & & \\
\hline GP8 & .862 & & & & \\
\hline OC1 & & & .781 & & \\
\hline $\mathrm{OC} 2$ & & & .805 & & \\
\hline OC3 & & & .794 & & \\
\hline OC4 & & & .825 & & \\
\hline OC5 & & & .855 & & \\
\hline OC6 & & & .848 & & \\
\hline SP1 & & & & & .758 \\
\hline SP2 & & & & & .794 \\
\hline SP3 & & & & & .832 \\
\hline SP4 & & & & & .825 \\
\hline SP5 & & & & & .818 \\
\hline SP6 & & & & & .838 \\
\hline
\end{tabular}

The above table outcomes show that all the rotated component matrix values are more than 0.7 (standard value) means at their threshold range. Therefore, it becomes clearly seen that all the variables are effectively loaded in the model and no more confusion is made regarding the factor uploading method. Well, it is convergent and discriminant validity based statistical outcomes are shown in the following table 5. 
JOURNAL OF SECURITY AND SUSTAINABILITY ISSUES

ISSN 2029-7017/ISSN 2029-7025 (online)

2020 Volume 10 Number (October)

http://doi.org/10.9770/jssi.2020.10.Oct(3)

Table 5: Convergent and Discriminant Validity

\begin{tabular}{lllllllll}
\hline & CR & AVE & MSV & OC & GTI & GH & SP & GP \\
\hline OC & 0.953 & 0.775 & 0.341 & $\mathbf{0 . 8 8 0}$ & & & & \\
GTI & 0.946 & 0.689 & 0.265 & 0.452 & $\mathbf{0 . 8 3 0}$ & & & \\
GH & 0.951 & 0.764 & 0.252 & 0.488 & 0.495 & $\mathbf{0 . 8 7 4}$ & & \\
SP & 0.948 & 0.754 & 0.294 & 0.450 & 0.515 & 0.482 & $\mathbf{0 . 8 6 8}$ & $\mathbf{0 . 9 1 9}$ \\
GP & 0.917 & 0.844 & 0.341 & 0.584 & 0.487 & 0.502 & 0.542 & \\
\hline
\end{tabular}

According to the above table, composite reliability values of each tested variable is more than 0.7 based standard value, while its average variance extracted value is higher than 0.5 which means there no convergent validity issue faced in these variables uploading mechanism. In addition to this, the bold letters of each variable in the decreasing order explores the non-existence of any discriminant validity issue within this SPSS test outcome. This table is important to justify the authenticity of the results that will be generated in the CFA and SEM-based analytical outcomes (see Table 6).

Table 6: Model Fit Indices

\begin{tabular}{llllll}
\hline CFA Indicators & CMIN/DF & GFI & IFI & CFI & RMSEA \\
\hline Threshold Value & $\leq 3$ & $\geq 0.80$ & $\geq 0.90$ & $\geq 0.90$ & $\leq 0.08$ \\
Observed Value & 2.855 & 0.811 & 0.948 & 0.948 & 0.068 \\
\hline
\end{tabular}

This model fit indices based outcomes show that all the observed values of CMIN/ DF, GFI, IFI, CFI, and RMSEA are within the threshold range. Like the value of CMIN/ DF is 2.855 , lower than standard 3, while, on the other side, GFI value is greater than 0.80 with 0.811 value outcomes. In addition, both values of IFI and CFI show the same outcomes 0.948 which is more than 0.90 value. In addition, its RMSEA value is 0.068 , lower than 0.08. All these observed values of this statistical model show that all the variables are effectively uploaded in the CFA model and this model is a good fit to make a constructive hypothesis outcome. Its graphical representation is shown in the following figure 3.

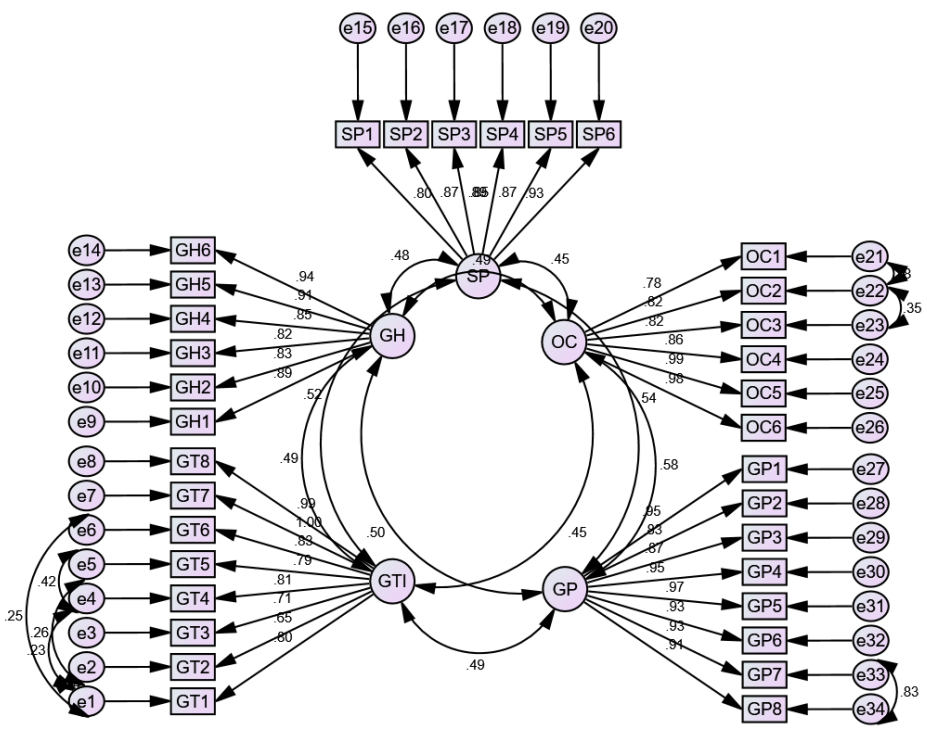

Figure 3: CFA 
The above figure shows that all the variables are equally uploaded in this model, while the structural equation modelling based outcomes show the valid outcomes of this analysis. Its tabular representation is given below (Table 7).

Table 7: Structural Equation Modeling

\begin{tabular}{lllll}
\hline Total effect & GreenPM & GreenTrIn & GreenHire & OrgCitBeh \\
\hline OrgCitBeh & $.384 * *$ & $.187^{* *}$ & $.187^{* *}$ & .000 \\
EnvSPerf & $.275^{* *}$ & $.306^{* *}$ & $.154^{* *}$ & $.211^{* *}$ \\
Direct Effect & GreenPM & GreenTrIn & GreenHire & OrgCitBeh \\
OrgCitBeh & $.384 * *$ & $.187 * *$ & $.187 * *$ & .000 \\
EnvSPerf & $.194 * *$ & $.267 * *$ & $.117^{*}$ & $.211^{* *}$ \\
Indirect Effect & GreenPM & GreenTrIn & GreenHire & OrgCitBeh \\
OrgCitBeh & .000 & .000 & .000 & .000 \\
EnvSPerf & $.081 * *$ & $.039 * *$ & $.039 * *$ & .000 \\
\hline
\end{tabular}

According to the above structural equation, modeling based statistical outcomes, it becomes clear that there is a direct relationship among the tested independent, mediating and independent variables. Like one percent deviation in the mediator role of organizational citizenship behavior, cause a $21.1 \%$ change in the environmental sustainability performance factor (Thaker et al., 2020). Similar to this, the independent variables cause a direct impact on both these variables. Fore-example, one percent change in green performance management \& compensation creates a $38.4 \%$ influence on organizational citizenship behavior and $27.5 \%$ on environmental sustainable performance. Well, in the case of green training \& involvement factor, the $18.7 \%$ change occurred on a mediator and $30.6 \%$ on the dependent variable. Last, but not the least, one percent change in the green hiring produces an $18.7 \%$ change on the efficiency of organizational citizenship behavior, and $15.4 \%$ deviation occurred on environmental sustainable performance. All these statistical outcomes depict that there is a great influence of green human resource management practices within an organizational structure and its performance. Its graphical representation is shown in the following figure 4.

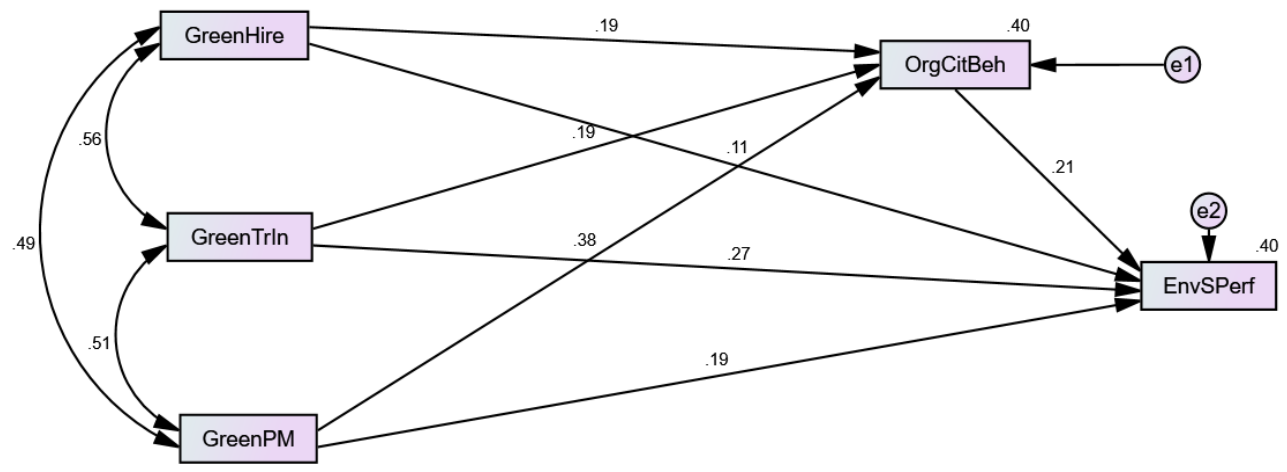

Figure 4: SEM 
JOURNAL OF SECURITY AND SUSTAINABILITY ISSUES

ISSN 2029-7017/ISSN 2029-7025 (online)

2020 Volume 10 Number (October)

http://doi.org/10.9770/jssi.2020.10.Oct(3)

\section{Discussion and Conclusion}

\subsection{Discussion}

According to the above-mentioned statistical outcomes, it becomes clear that the influence of green performance management \& compensation is majorly effected the organizational citizenship behavior as compared to the other independent variables that cause a similar impact on the mediating variable. While, the green training and involvement factor cause a major influence on the environmental sustainable performance which means if the management majorly works on enhancing its green HRM-related strategical approach, then more productive outcomes will be generated that will add values in their future performance (Nankervis, Baird, Coffey, \& Shields, 2019). After this, the green performance management \& compensation factors directly influence the perfect environmental sustainable performance and motivate the employees to remain loyal with the company and work hard to meet their standards (Lockie, 2019). While, the green hiring is the least effecting variable on the dependent and mediating variables which shows that Indonesian employees are not majorly affected by such an innovative hiring mechanism. While, they only impressed by the environment-oriented training, involvement, compensation, and other efficient performance management that hit their perception level towards the company's operation and feel themselves to be the part of the company. This strategic approach enhances the internal capabilities and motivation level of the employees to upgrade their capabilities towards the efficient sustainable development of a company. Mousa and Othman also explained this important strategic concept that over the past few years, there is great pressure on organizations from their stakeholders to adopt the environmental friendly business practices. In that perspective, the healthcare organization and its strategic policies are majorly affected to implement advanced green HRM policies in their operating activities (Mousa \& Othman, 2020). In the International Journal of Manpower, Peter with others depicted that there is a need of new typological environmentally sustainable HRM evaluation based mechanisms in the current advanced technological era. Their resource-based theory explains the training of recruiters in the green candidate assessment within the HR decision making process is the best approach to develop a sustainable development of a company in the diverse competitive market (Adjei-Bamfo, Bempong, Osei, \& Kusi-Sarpong, 2019).

\subsection{Conclusion and Future Implications}

Thus, after critically evaluate the structural equation modelling based statistical outcomes, it becomes concluded that the green performance management \& compensation caused a major impact on both variables, named as organizational citizenship behavior and environment sustainable performance. According to the participants' outcomes, green hiring has the least impact on the sustainable citizenship behavior among the Indonesian employees, while green training \& involvement factor cause a moderate impact on the behavioral approach of the healthcare HRM efficiency. This online data-based quantitative research depicts that if the healthcare management sector in Indonesia made some productive and green HR-related strategies, then more favorable outcomes will be generated in the future that enhances the sustainable growth rate of this industry. This study will be informative for the healthcare sector and its management to consider organizational citizenship behavior through green HRM bundles. In addition, this data can utilize by policymakers and other related researchers to make a constructive and long-lasting decision-making process.

\subsection{Limitations and Future Researches}

In addition to its implication, some weaknesses/ deficiencies of this paper may affect the authenticity of its analysis. Like there is a lack of interviews or mixed method of research to generate a versatile research. Also, only Indonesian's healthcare sector and its related employee's data is considered for statistical analysis. If its statistics are compared with the other developed countries' healthcare sector, then a more reliable and authentic outcome will be generated. In addition, there is a lack of data regarding the employee's turnover factor in the green HRM practices that affect this research validity. Therefore, there is a chance in front of future scholars to cover its limitations and derive a productive and informative research analysis. 
JOURNAL OF SECURITY AND SUSTAINABILITY ISSUES

ISSN 2029-7017/ISSN 2029-7025 (online)

2020 Volume 10 Number (October)

http://doi.org/10.9770/jssi.2020.10.Oct(3)

\section{References}

Adjei-Bamfo, P., Bempong, B., Osei, J., \& Kusi-Sarpong, S. (2019). Green candidate selection for organizational environmental management. International Journal of Manpower.

https://www.emerald.com/insight/content/doi/10.1108/IJM-10-2019-0480/full/html

Adriana, L. T. D., Fahira, K. T., Nailissa'adah, M., \& El Maula, H. (2020). A Review the Important of Green Human Resource Management Practices toward Employee Green Behaviour in Organization. Paper presented at the Journal of International Conference Proceedings.

http://ejournal.aibpm.org/index.php/JICP/article/view/787

Afsar, B., \& Badir, Y. F. (2016). Person-organization fit, perceived organizational support, and organizational citizenship behavior: The role of job embeddedness. Journal of Human Resources in Hospitality \& Tourism, 15(3), 252-278.

Ahmed, U., AlZgool, M. R. H., \& Shah, S. M. M. (2019). The impact of green human resource practices on environmental sustainability. Polish Journal of Management Studies, 20.

Ahmed, S., Iqbal, A., \& Farooqi, M. T. K. (2020). A STUDY OF TEACHERS'TEACHING STYLES AND STUDENTS'PERFORMANCE. Hamdard Islamicus, 43(3), 83-92.

http://yadda.icm.edu.pl/baztech/element/bwmeta1.element.baztech-242908c4-d271-4386-8c24-6f81f9539683

Amrutha, V., \& Geetha, S. (2020). A systematic review on green human resource management: Implications for social sustainability. Journal of Cleaner Production, 247, 119131.

Assyofa, A. R., Rani, A. M., \& Yuliawati, T. (2020). Green Behaviors Factors on Green Human Resources Management Practice on the Employees of "The First Movers on Sustainable Banking" in Indonesia. Paper presented at the 2nd Social and Humaniora Research Symposium (SoRes 2019).

https://www.atlantis-press.com/proceedings/sores-19/125935366

Astuti, M., \& Wahyuni, H. (2018). Green human resource management implication on increasing productivity of small and medium enterprises. IPTEK Journal of Proceedings Series(3), 170-173.

Birou, L. M., Green, K. W., \& Inman, R. A. (2019). Sustainability knowledge and training: Outcomes and firm performance. Journal of Manufacturing Technology Management.

Bombiak, E. (2019). Green human resource management - the latest trend or strategic necessity? Entrepreneurship and Sustainability Issues, 6(4), 1647-1662. http://doi.org/10.9770/jesi.2019.6.4(7)

Bon, A. T., Zaid, A. A., \& Jaaron, A. (2018). Green human resource management, green supply chain management practices and sustainable performance. Paper presented at the 8th International Conference on Industrial Engineering and Operations Management (IEOM),(Bandung, Indonesia) March.

Cabral de Andrade, M. O., González-Víllora, S., Casanova, F., \& Teoldo, I. (2020). The Attention As a Key Element to Improve Tactical Behavior Efficiency of Young Soccer Players. Revista de Psicologia del Deporte, 29(2).

Center, I. K. (2018). KMO and Bartlett's Test.

Cheema, S., \& Javed, F. (2017). The effects of corporate social responsibility toward green human resource management: The mediating role of sustainable environment. Cogent Business \& Management, 4(1), 1310012.

Chen, M., \& Gao, X. (2020). Psychological mechanism between impression management and compulsory citizenship behavior of employees. Revista Argentina de Clinica Psicologica, 29(1), 141-148. https://doi.org/10.24205/03276716.2020.18

Chen, Qisheng, Li, X., Wang, J., Liu, K., \& Li, L. (2020). Psychological perception-based analysis on the influence of entrepreneurship education on entrepreneurial intention. Revista Argentina de Clinica Psicologica, 29(1), 117-130. https://doi.org/10.24205/03276716.2020.16

https://www.cogentoa.com/article/10.1080/23311975.2017.1310012

Dreyer, N. A., Macedo, A. F., \& Velentgas, P. (2019). Primary Data Collection for Pharmacoepidemiology. Pharmacoepidemiology, 342354.

Groves, P., Kayyali, B., Knott, D., \& Kuiken, S. V. (2016). The'big data'revolution in healthcare: Accelerating value and innovation.

Guerci, M., \& Carollo, L. (2016). A paradox view on green human resource management: Insights from the Italian context. The International Journal of Human Resource Management, 27(2), 212-238.

https://www.tandfonline.com/doi/abs/10.1080/09585192.2015.1033641

Hameed, W. U., Basheer, M. F., Iqbal, J., Anwar, A., \& Ahmad, H. K. (2018). Determinants of Firm's open innovation performance and the role of R \& D department: an empirical evidence from Malaysian SME's. Journal of Global Entrepreneurship Research, $8(1), 29$.

Hussain, H.I., Kamarudin, F., Mohamad Anwar, N.A., Nassir, A.M., Sufian, F., Mang Tan, K. (2020), Impact of Country’s Governance Dimensions on Bank Revenue Efficiency: Overview on Middle East, Southeast Asia, and South Asia Countries, Transformations in Business \& Economics, 19 (1), 191-228. http://www.transformations.knf.vu.lt/49/article/impa.

Hussain, H.I., Kamarudin, F., Thaker, H.M.T. \& Salem, M.A. (2019) Artificial Neural Network to Model Managerial Timing Decision: Non-Linear Evidence of Deviation from Target Leverage, International Journal of Computational Intelligence Systems, 12 (2), 1282-1294. https://doi.org/10.2991/ijcis.d.191101.002

Jiang, W., Zhao, X., \& Ni, J. (2017). The impact of transformational leadership on employee sustainable performance: The mediating role of organizational citizenship behavior. Sustainability, 9(9), 1567. 
JOURNAL OF SECURITY AND SUSTAINABILITY ISSUES

ISSN 2029-7017/ISSN 2029-7025 (online)

2020 Volume 10 Number (October)

http://doi.org/10.9770/jssi.2020.10.Oct(3)

https://www.mdpi.com/2071-1050/9/9/1567

Kanwal, N., Khan, M., \& Kanwal, N. (2020). Mixed Methods Analysis of Factors Influencing Self-Efficacy In Student-Teachers During Teaching Practices. Hamdard Islamicus, 43(3), 68-82.

Kim, Y. J., Kim, W. G., Choi, H.-M., \& Phetvaroon, K. (2019). The effect of green human resource management on hotel employees' ecofriendly behavior and environmental performance. International Journal of Hospitality Management, 76, 83-93.

https://www.sciencedirect.com/science/article/abs/pii/S0278431917306588

Lockie, S. (2019). Failure Or Reform?: Market-based Policy Instruments for Sustainable Agriculture and Resource Management: Routledge.

Lubis, H., Pratama, K., Pratama, I., Pratami, A. (2019). A Systematic Review of Corporate Social Responsibility Disclosure. International Journal of Innovation, Creativity and Change Vol, 6(9), 415-428.

Lu, H., Yue, A., Han, Y., \& Chen, H. (2018). Exploring the Effect of Different Performance Appraisal Purposes on Miners' Organizational Citizenship Behavior: The Mediating Role of Organization Identification. Sustainability, 10(11), 4254.

https://www.mdpi.com/2071-1050/10/11/4254

Luu, T. T. (2017). CSR and organizational citizenship behavior for the environment in hotel industry. International Journal of Contemporary Hospitality Management.

Luu, T. T. (2019). Green human resource practices and organizational citizenship behavior for the environment: the roles of collective green crafting and environmentally specific servant leadership. Journal of Sustainable Tourism, 27(8), 1167-1196.

https://www.tandfonline.com/doi/abs/10.1080/09669582.2019.1601731

Mazzoni, F. (2020). Circular economy and eco-innovation in Italian industrial clusters. Best practices from Prato textile cluster. Insights into Regional Development, 2(3), 661-676. https://doi.org/10.9770/IRD.2020.2.3(4)

McGuire, S. J., Drost, E. A., \& Zhang, Y. (2016). Convergent and Discriminant Validity of a Model of Entrepreneurial Culture. Paper presented at the ISPIM Innovation Symposium.

Mishra, P. (2017). Green human resource management: A framework for sustainable organizational development in an emerging economy. International Journal of Organizational Analysis, 25(5), 762-788.

Mousa, S. K., \& Othman, M. (2020). The impact of green human resource management practices on sustainable performance in healthcare organisations: A conceptual framework. Journal of Cleaner Production, 243, 118595.

https://www.sciencedirect.com/science/article/abs/pii/S0959652619334651

Nankervis, A., Baird, M., Coffey, J., \& Shields, J. (2019). Human resource management: Cengage AU.

Niyomdecha, L., \& Yahya, K. K. (2019). Examining The Relationship Between Human Resource Managemnt Practices And Organizational Citizenship Behavior For Environment Among Administrative Staff In A Thailand University. Sains Humanika, $11(2-2)$.

https://sainshumanika.utm.my/index.php/sainshumanika/article/view/1653

Nuryakin, Maryati, T. (2020). Green product competitiveness and green product success. Why and how does mediating affect green innovation performance? Entrepreneurship and Sustainability Issues, 7(4), 3061-3077. https://doi.org/10.9770/jesi.2020.7.4(33)

Ojo, A. O., \& Raman, M. (2019). Role of Green HRM practices in employees' pro-environmental IT Practices. Paper presented at the World Conference on Information Systems and Technologies.

https://link.springer.com/chapter/10.1007/978-3-030-16181-1_64

Owino, W. A., \& Kwasira, J. (2016). Influence of selected green human resource management practices on environmental sustainability at Menengai Oil Refinery Limited Nakuru, Kenya. J. Hum. Resour. Manag, 4, 19-27.

Pasharibu, Y., Sugiarto, A., Ariarsanti, T., \& Wijayanto, P. (2019). Dimensions of Green Office evidence from regency/city government offices in Central Java, Indonesia. Business: Theory and Practice, 20, 391-402.

Pham, N. T., Tučková, Z., \& Jabbour, C. J. C. (2019). Greening the hospitality industry: How do green human resource management practices influence organizational citizenship behavior in hotels? A mixed-methods study. Tourism Management, 72, $386-399$.

https://www.sciencedirect.com/science/article/abs/pii/S0261517718303121

Prasad, K., Rao, M., \& Vaidya, D. R. (2019). Factors Effecting Performance Management System: An Empirical Analysis with Reference to Health Care Industry around Hyderabad Metro. International Journal of Management (IJM), 10(6).

Pratama, I., Che-Adam, N., Kamardin. N. (2019). Corporate social responsibility disclosure (CSRD) quality in Indonesian public listed companies. Polish Journal of Management Studies, 20 (1), 359-371.

Pratama, I., Che-Adam, N., Kamardin. N., (2020). Corporate Governance and Corporate Social Responsibility Disclosure Quality in Indonesian Companies. International Journal of Innovation, Creativity and Change Vol 13(4), 442-463.

Reinhold, K., Järvis, M. \& Prause, G. (2019). Occupational health and safety aspects of green shipping in the Baltic Sea, Entrepreneurship and Sustainability Issues, 7(1), 10-24. http://doi.org/10.9770/jesi.2019.7.1(1)

Ren, S., Tang, G., \& Jackson, S. E. (2018). Green human resource management research in emergence: A review and future directions. Asia Pacific Journal of Management, 35(3), 769-803.

https://link.springer.com/article/10.1007/s10490-017-9532-1

Rimkeviciene, J., Hawgood, J., O'Gorman, J., \& De Leo, D. (2017). Construct validity of the acquired capability for suicide scale: Factor structure, convergent and discriminant validity. Journal of Psychopathology and Behavioral Assessment, 39(2), $291-302$.

https://link.springer.com/article/10.1007/s10862-016-9576-4 
JOURNAL OF SECURITY AND SUSTAINABILITY ISSUES

ISSN 2029-7017/ISSN 2029-7025 (online)

2020 Volume 10 Number (October)

http://doi.org/10.9770/jssi.2020.10.Oct(3)

Roscoe, S., Subramanian, N., Jabbour, C. J., \& Chong, T. (2019). Green human resource management and the enablers of green organisational culture: Enhancing a firm's environmental performance for sustainable development. Business Strategy and the Environment, 28(5), 737-749.

Singh, S. K., Del Giudice, M., Chierici, R., \& Graziano, D. (2020). Green innovation and environmental performance: The role of green transformational leadership and green human resource management. Technological Forecasting and Social Change, 150, 119762.

https://www.sciencedirect.com/science/article/pii/S0040162519309588

Tarhini, A., Teo, T., \& Tarhini, T. (2016). A cross-cultural validity of the E-learning Acceptance Measure (ElAM) in Lebanon and England: A confirmatory factor analysis. Education and Information Technologies, 21(5), 1269-1282.

Thaker, H. M. T., Sakaran, K., Nanairan, N., Thaker, M. M. T. and Hussain, H. I. (2020), Drivers of loyalty among non-Muslims towards Islamic banking in Malaysia: Evidence from SmartPLS, International Journal of Islamic and Middle Eastern Finance and Management, 13 (2), 281 - 302. https://doi.org/10.1108/IMEFM-07-2018-0211

Valencia, G. A. D., Norato, O. M. G., Paéz, A. A. V., \& Romero, R. (2020). Formas de financiación informal de los comerciantes informales en Colombia Casos: Cúcuta, Ibagué y Villavicencio. Cuadernos de Economía, 43(123). https://doi.org/10.32826/cude.v43i123.126

Wongleedee, K. (2020). The Effects of GHRM and GSCM on the Sustainable Performance of the Thailand Pharmacies: Mediating Role of Employee Performance. Systematic Reviews in Pharmacy, 11(1), 371-379.

Yong, J. Y., Yusliza, M., Ramayah, T., \& Fawehinmi, O. (2019). Nexus between green intellectual capital and green human resource management. Journal of Cleaner Production, 215, 364-374.

Yow, M. C. (2016). Employee interpretations of organizational citizenship behavior in tertiary sector organizations: A generic qualitative study. Capella University.

Yu, W., Chavez, R., Feng, M., Wong, C. Y., \& Fynes, B. (2020). Green human resource management and environmental cooperation: An ability-motivation-opportunity and contingency perspective. International Journal of Production Economics, 219, $224-235$.

Zaid, A. A., Bon, A., \& Jaaron, A. (2018). Green human resource management bundle practices and manufacturing organizations for performance optimization: a conceptual model. International Journal of Engineering \& Technology, 7(3.20), 87-91.

Zaid, A. A., Jaaron, A. A., \& Bon, A. T. (2018). The impact of green human resource management and green supply chain management practices on sustainable performance: An empirical study. Journal of Cleaner Production, 204, 965-979.

Zhao, H., \& Zhou, Q. (2019). Exploring the impact of responsible leadership on organizational citizenship behavior for the environment: A leadership identity perspective. Sustainability, 11(4), 944.

Register for an ORCID ID:

https://orcid.org/register

This work is licensed under the Creative Commons Attribution International License (CC BY). http://creativecommons.org/licenses/by/4.0/

(c) (i) Open Access

